\section{Cyclophosphamide Tolerance as a Test for Antigenicity of Nucleic Acids}

Ir has been generally thought that nucleic acids are unable to elicit an immune response without carrier protein and adjuvant ${ }^{1}$. We have recently succeeded in accelerating the spontaneous formation of antibodies to RNA and DNA in New Zealand mice with polyinosinic - polycytidylic acid (poly I.C) without carrier protein or additional adjuvant ${ }^{2}$. We have also made New Zcaland mice immuno. logically tolerant to subsequent challenge with poly I.C in complete Freund's adjuvant by pretreatment with poly I.C followed by cyclophosphamide ${ }^{3}$. These studies in mice that spontaneously develop antibodies to nucleic acids suggested that poly I.C was immunogenic but did not prove that nucleic acids could be recognized innmunologically by normal mice. We now report the induction of immunological tolerance to poly I.C in normal strains of mice as a method of demonstrating immunological recog. rition of this nucleic acid.

Multiple injections of poly I.C without adjuvant failed to immunize three normal strains of mice ${ }^{3}$. We havo further attempted to detect very low levels of antibody to poly $\mathrm{I} \cdot \mathrm{C}$ in $\mathrm{C} 57 \mathrm{Bl} / 6, \mathrm{Balb} / \mathrm{c}$, and $\mathrm{C} 3 \mathrm{H} / \mathrm{He}$ mice treated with twelve injections of poly I.C (75-100 $\mu \mathrm{g} /$ injection). Antigen binding capacities by the ammonium sulphate precipitation method ${ }^{3}$ have been less than $0.04 \mu \mathrm{g} / \mathrm{ml}$, the limit of sensitivity of our assay.

To study further whether normal strains of mice immunologically recognize poly I.C without carrier or adjuvant, we tried to induce immunological tolerance with cyclophosphamide. One month old Balb/c and DBA/2, and 1-3 month old C57Bl/6 mico of both sexes were in. jected intraperitoneally with either poly I.C $(100 \mu \mathrm{g})$ or bovine $\gamma$-globulin, BGG (500 $\mu$ g, not ultracentrifuged), and $24 \mathrm{~h}$ later given cyclophosphamide intraperitoneally $(75 \mu \mathrm{g} / \mathrm{g}$ body weight $)$. Eight days later all mice were challenged intraperitoneally with $150 \mu \mathrm{g}$ of poly I.C in complete Freund's adjuvant. Antibody levels measured 13 days later by the ammonium sulphato precipitation assay ${ }^{3}$ are listed in Table 1. Much lower levels of antibody to poly I.C were found in mice pretreated with poly $\mathrm{I} \cdot \mathrm{C}$ plus eyclophosphamide than in control mico pretreated with BGG plus cyclophosphamide. Thus these mice were made immunologically hyporesponsive to challenge with poly $\mathrm{I} \cdot \mathrm{C}$ in adjuvant by pretreatment with poly I.C plus cyclophosphamide, indicating that immuno cells were induced to proliferate by antigenic recognition of poly I.C and were destroyed by the cyclophosphamide.

Table 1. TOLERANCE TO POLY I. $\mathrm{C}$ IN NORMAL MIICE

\begin{tabular}{|c|c|c|}
\hline Strain* & $\begin{array}{l}\text { Mean poly I. } \mathrm{C} \text { bi } \\
\text { BGG plus } \\
\text { cycloplosphamido }\end{array}$ & $\begin{array}{l}\text { capacity }(\mu \mathrm{g} / \mathrm{ml} .) \\
\text { Poly I.C plus } \\
\text { cyclophosphamide } \dagger\end{array}$ \\
\hline C57Bl/6 & 1.5 & $<0.04$ \\
\hline $\mathrm{Balb} / \mathrm{c}$ & $6 \cdot 1$ & 0.2 \\
\hline $\mathrm{DBA} / 2$ & $8 \cdot 7$ & 0.6 \\
\hline
\end{tabular}

* Twenty animals in each group.

$+P<0.01$ compared with BGG controls for each strain ( $t$ test).

The specificity of the tolerance to poly I.C was investigated in $\mathrm{DBA} / 2$ and $\mathrm{C} 57 \mathrm{Bl} / 6$ mice. These mice were treated with poly I.C plus eyclophosphamide and then immunized with sheep erythrocytes. Antibody forming cells to shcep erythrocytes were enumerated by the Jerne plaque assay. Mice made tolerant to poly I.C made normal immune responses to sheep erythrocytes, indicating that the tolerance to poly I.C showed immunologic specificity.

Using this technique of cyclophosphamide induced tolerance, we have also found that a double stranded DNA, dAT, is antigenic in New Zealand mice.

The exact mechanism of this phenomenon is not clear. We may be eliminating the small number of cells capable of responding to the nucleic acid, a number perhaps too small to produce a detectable antibody response without adjuvant. On the other hand, if cooperation of two cell types is necessary for the response to tho antigen in adjuvant, we may be selectively eliminating one of the populations of cells necessary for the response. Whatever the exact mechanism, cyclophosphamido tolerance may be a useful test for the antigenicity of a variety of sub. stances which, like nucleic acids, have not previously been thought to be recognized immunologically.
A. D. STeinberg
T. M. Chused
M. E. JACOBS
N. Talal

Arthritis and Rheumatism Branch,

National Institute of Arthritis and Metabolic Diseases,

National Institutes of Health,

Bethesda, Maryland 20014.

Received May 4, 1970.

${ }^{1}$ Nucleic Acids in Immunology (edit. by Plescla, O. J., and Braun, W.) (Springer-Verlag, New York, 1968).

2 Steinberg, A. D., Baron, S., and Talal, N., Proc. US Nat. Acad. Sci., 63,

${ }^{3}$ Steinberg, A. D., Daley, G. G., and Tala1, N., Science, 16\%, 870 (1970).

\section{Antigenic Determinants in Amyloid Deposits}

Precise analyses of human amyloid laden tissues have shown that they contain at least two specific componentsa fibrillar protein of uniform cross-sectional diameter ${ }^{1,2}$ and a rod-shaped protein (P-component). Units of the latter look pentagonal under the electron microscope and show antigenic identity with an $\alpha$-globulin present in human plasma ${ }^{3-5}$. Preliminary studies have also suggested that the fibrillar component of amyloid is non-immunogenic whereas the P-component is capable of eliciting a strong antibcdy response ${ }^{6-8}$. Recently, we have succecded in preparing antisera not only to the P-component but also to alkali degraded arnyloid fibrils (DAM), according to the method of Pras et al. ${ }^{9}$. Here we show that theso antisera react not only with DAM but also with amyloid

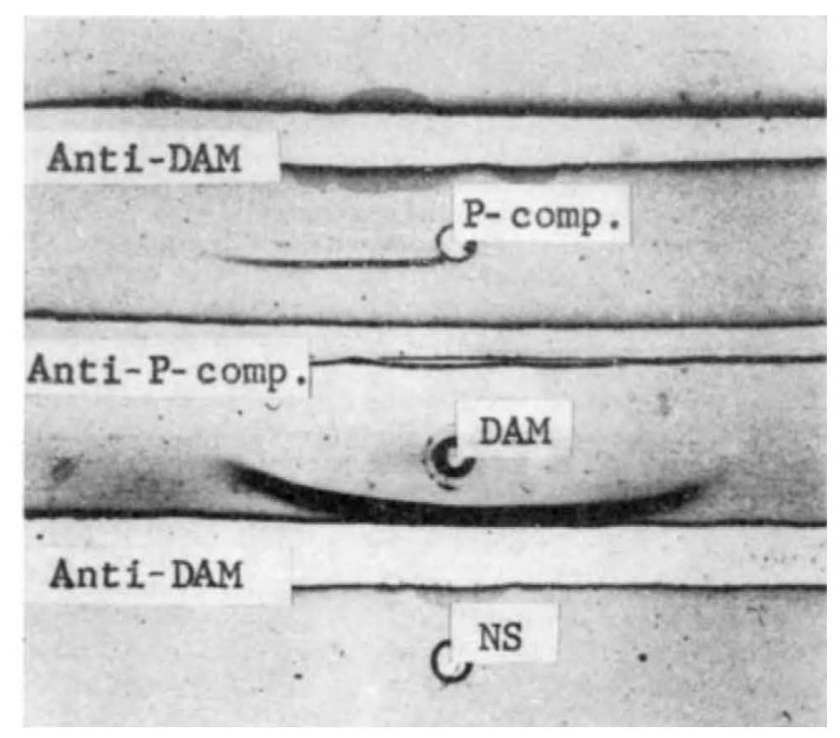

Fig. 1. Immunoelectrophoresis of amyloid components. P-component (P-comp.) forms a single precipitin line against anti-P-component antiserum (anti-P-comp.) but fails to react with anti-DAM antiserum DAM forms a single precipitin line against anti-DAM antiserum but fails anti-DAM. 